Winter 2003

\title{
The Community Political Order
}

\author{
Paul Craig \\ St. John's College, Oxford
}

Follow this and additional works at: https://www.repository.law.indiana.edu/ijgls

Part of the International Law Commons

\section{Recommended Citation}

Craig, Paul (2003) "The Community Political Order," Indiana Journal of Global Legal Studies: Vol. 10 : Iss. 1 , Article 5.

Available at: https://www.repository.law.indiana.edu/ijgls/vol10/iss1/5

This Symposium is brought to you for free and open access by the Law School Journals at Digital Repository @ Maurer Law. It has been accepted for inclusion in Indiana Journal of Global Legal Studies by an authorized editor of Digital Repository @ Maurer Law. For more information, please contact rvaughan@indiana.edu.

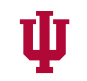

JEROME HALL LAW LIBRARY INDIANA UNIVERSITY Maurer School of Law
Blooming ton 


\title{
The Community Political Order
}

\author{
PROFESSOR PAUL CRAIG
}

It is self-evident that the European Economic Community's political order has evolved over time. Understanding the nature of this evolution and, the forces which drove it, is more difficult. This paper attempts to explicate this development. The analysis is necessarily temporal, with the main staging posts being the Treaty revisions that have taken place since the inception of the EEC. The trip through the Treaties is like a geographical tour, with some places well known and others much less so. Rome, Maastricht, Amsterdam and Nice are all featured on the trip, while not forgetting the Single European Act, which was never graced with the name of a physical place. The shifting institutional balance between Council, European Council, Commission and European Parliament provides the comerstone of the analysis. The evolution of this institutional balance is examined not only in relation to the changes wrought by successive Treaty amendment, but also through consideration of developments outside the letter of the Treaty which have had a marked impact on the institutional disposition of power. Woven into the study is literature on integration that seeks to explain the motivation behind integration and cannot therefore be ignored in an examination of the evolution of the political order. An understanding of this evolution is essential for any reasoned inquiry into legitimacy and democracy.

\section{FROM THE ROME TREATY TO THE SINGLE EUROPEAN ACT}

\section{A. The Rome Treaty: Conceptual Foundations of the Original Political Order}

The original Rome Treaty encapsulated a particular institutional balance between the Council, Commission and Assembly. It was clear that the main repositories of power were the Council and the Commission., and that the Assembly was accorded little real power in the original Treaty.

\footnotetext{
* Professor of English Law, St. John's College, Oxford.
} 
This distribution of power is readily apparent in relation to the distribution of legislative competence. The Commission possessed the right of legislative initiative, which enabled it to function as the "engine room" of the Community, and to set its agenda. This role was enhanced by the fact that the Commission had the bureaucratic structure to fashion the legislative proposals that were needed to flesh out the bare bones of the Treaty during the all-important transitional period. The Council's principal power in the legislative process was its right to vote on the measures suggested by the Commission. The Assembly, for its part, was largely excluded from this process, notwithstanding its indirect democratic credentials. It only had the power to be consulted on legislation emanating from the Commission, and then only when the Treaty so specified. In large part the legislative process was one in which "the Commission proposed, and the Council disposed." The balance of power between the Council and Commission was itself shaped by the detail of Article 145 . $^{1}$ This provided that the Commission could alter its original proposal as long as the Council had not yet acted, but after the Council had acted on a proposal, unanimity would be required in the Council for any amendment to the proposal. The general message from the Rome Treaty was clear: the Council would have to vote approval for Commission legislative initiatives, but the Commission was free to modify its proposal up to the last minute, while the Council could not easily amend or tinker with the details.

The centrality accorded to the Commission was further underlined by the other powers it possessed. These were not readily apparent from the face of Article 155 itself. $^{2}$ The Commission was the principal administrative organ within the Community, and it would be responsible for ensuring that Community legislation was implemented. This would normally entail close ties with national bureaucracies, thereby setting the pattern for shared administration within the Community. The Commission was also accorded authority of an executive nature, as exemplified by its powers over the budget, and negotiation with third states, and other international organizations. The Rome Treaty also gave the Commission an important role in the judicial process. It was the Commission which prosecuted recalcitrant states before the

1. Treaty Establishing the European Economic Community, Mar. 25, 1957, art. 145, 298 U.N.T.S. 11.

2. Id., art. 155 . 
$\mathrm{ECJ}$, and it was the Commission which was the initial judge in significant areas such as competition policy and state aids.

This institutional balance and disposition of authority can only be properly understood by seeing it against the intellectual background present in the late 1950s and early 1960s. Neofunctionalism was the early, dominant ideology of Community integration. ${ }^{3}$ It embodied a pluralist theory of international politics, ${ }^{4}$ in the sense that it was not based on the assumption that the state was a single unified actor, nor did it assume that states were the only players on the international stage. For neofunctionalists "the actions of a state were the outcome of a process in which political decisionmakers were influenced by various pressures," including state level bureaucratic actors, societal interest groups, and multinational corporations. These groups were expected to forge links across national boundaries with respective groups in other states. It was also central to neofunctionalist thought that the Commission itself would be a decisive force in the integration process, being able to orchestrate, manipulate and maximize the drive towards Community integration, even when this did not accord with the wishes of some Member States. The central tenet of neofunctionalism was the concept of "spillover," which had both a functional and a political dimension. ${ }^{6}$

Functional spillover was an intuitively simple and attractive idea, based as it was upon the interconnectedness of the economy. Different parts of the economy do not exist in isolation. If there was integration in one sphere it would, therefore, create pressure for integration to proceed in other areas.

The removal of formal tariff barriers and quotas with the object of facilitating the creation of a single market, would in turn generate a need to deal with non-tariff barriers which could have an equally destructive impact on cross-border trade. This very same desire to create a single market with a level

3. See generally ERNST B. HAAS, The UNITING Of EUROPE: POLITICAL, SOCIAL AND ECONOMIC FORCES 1950-1957 (Stanford University Press 1968) (1958); LEON N. LINDBERG, THE POLITICAL DYNAMICS OF EUROPEAN ECONOMIC INTEGRATION (1963); LEON N. LINDBERG \& STUART A. SCHEINGOLD, EUROPE'S WOULD-BE POLITY: PATTERNS OF CHANGE IN THE EuROPEAN COMMUNITY 7 (1970) [hereinafter LINDBERG, EUROPE'S WOULD-BE POLITY]; LEON N. LINDBERG \& STUART A. SCHEINGOLD, REGIONAL INTEGRATION: THEORY AND RESEARCH (1971) [hereinafter LINDBERG \& SCHENGOLD, REGIONAL [NTEGRATION].

4. Stephen George, Politics and Policy In THE European Union 36 (3rd. ed. 1996).

5. Id.

6. Id. at 37 . 
playing field between the states would then lead to other matters being decided at Community level. ${ }^{7}$

Political spillover was equally important to neofunctionalist ideas on integration. It involved the "build-up of political pressures in favour of further integration within the states involved." In areas which had been integrated, the relevant interest groups would then be expected to concentrate their attention on the Community level, consonant with the basic idea that "you shoot where the ducks are" and apply pressure on those who have the regulatory power. Such groups would also become mindful of the remaining barriers to interstate trade that were preventing them from reaping the full rewards of the integration, thereby adding to the political pressure for further union. Other interest groups in sectors not yet touched by the Community hand would come to perceive the benefits of integration and add their voice to the call for an expanded Community involvement. The Commission itself was to be a major player in this political spillover, since it would foster, encourage, and organise the very beliefs of the various state players.

The explanatory force of neofunctionalism has been attacked, empirically and theoretically. This will be considered in due course. It is the link between neofunctionalist thought and the institutional arrangements enshrined in the Rome Treaty which is of interest here. To understand this link it is necessary to take a step back to the very foundations of integration and to Jean Monnet's vision of Europe.

Monnet's conception of Europe was not surprisingly strongly influenced by his background and the role played by technocrats trained in the Grands Ecoles within the French bureaucracy. The structure of the ECSC can only be properly understood against this background. The centrality accorded to the High Authority was an expression of the technocratic approach, with action being initiated by experts. A corporatist style, involving networks of outside producer

7. This might be to prevent states from giving advantages to their own industries, thereby necessitating Community controls on state aid, public procurement and the like. It might remove yet more indirect barriers to intra-Community trade, hence the plethora of harmonization measures in areas as diverse as banking, trade marks and product liability. It might also preclude private actors from resurrecting national barriers to trade through the instrumentality of market division cartels, hence the need for a Community competition policy. The same forces might also be expected to produce demands for yet further modes of economic integration. A single market could, arguably, not truly be said to exist while single currencies persisted, hence the stimulus for a single currency. The very same interconnectedness between monetary union and other issues of macroeconomic policy might then be expected to give rise to further calls for economic union.

8. GEORGE, supra note 4 , at 38 . 
and interest groups, was the other legacy of Monnet's experience with planning authorities in France. ${ }^{9}$ This was institutionalized in the ECSC in the form of the Consultative Committee. Integration was to be based on the combination of benevolent technocrats and interest-propelled economic groups, which would build transnational coalitions in support of European policy. ${ }^{10}$ Monnet's strategy was thus for what has been termed elite-led gradualism, ${ }^{11}$ as opposed to a more dramatic leap towards federalism, favored by those such as Spinelli. It was hoped that popular consent would follow this lead, but the need to engage powerful business and labor organizations was accorded a much higher priority than the "direct involvement of as yet uninformed publics". ${ }^{2}$ The idea of a Parliamentary Assembly within the ECSC was not part of Monnet's original vision, although he did accept it at a relatively early point in the negotiations. The Assembly's powers were nonetheless very limited. The same general institutional structure was carried over to the foundation of the EEC: "enlightened administration on behalf of uninformed publics, in cooperation with affected interests and subject to the approval of national governments, was therefore the compromise again struck in the Treaties of Rome". ${ }^{13}$ While Monnet was in favor of a democratic Community, "he saw the emergence of loyalties to the Community institutions developing as a consequence of elite agreements for the functional organization of Europe, not as an essential prerequisite to that organization."14

Neofunctionalism was to be the vehicle through which the Community would realize integration, conceived of as technocratic, elite-led gradualism, combined with corporatist style engagement of affected interests. The predictions of neofunctionalism fitted neatly with Monnet's perception of the Community. The idea of spillover reinforced the sense that gradualism was a meaningful strategy for furthering integration. The neofunctionalist view of the important players in the integration process meshed with those of Monnet. The neofunctionalist emphasis on the importance of the High

\footnotetext{
9. Kevin Featherstone, Jean Monnet and the "Democratic Deficit" in the European Union, $32 \mathrm{~J}$. COMMON MKT. STUD. 149, 155 (1994).

10. Helen Wallace, European Governance in Turbulent Times, 31 J. CoMMON MKT. STUD. 300 (1993).

11. See William Wallace \& J. Smith, Democracy or Technocracy? European Integration and the Problem of Popular Consent, in THE CRISIS OF REPRESENTATION IN EUROPE 140 (J. Hayward ed., 1995).

12. Id.

13. Id. at 143 .

14. Martin Holland, EuRopean COMmunity INTEGRATION 16 (1993) (emphasis omitted).
} 
Authority/Commission in enhancing integration fostered the self-image of technocratic elites at the heart of Europe.

For Monnet and kindred spirits the legitimacy of the Community was to be secured through its outcomes: peace and prosperity. The ECSC was established in part to render a third European war impossible. The preamble to the ECSC Treaty bears striking testimony to this fact. Let us not forget that while the founders of the EEC Treaty hoped that it would lead to further political integration, they were also fully mindful of the direct economic benefits of a common market. Peace and prosperity were then potent benefits to hold out to peoples who had been through a catastrophic war in the recent past, and who even in the 1950s were living with the Cold War as an ever present reminder of the fragility of present gains. Democracy was, by way of contrast, a secondary consideration in a double sense. First, it was felt that the best or perhaps only way of securing the desired peace and prosperity was by technocratic elite-led guidance. Additionally, even when attention was focused on the "people," the notion of democracy was limited or attenuated. The essence of the discussion was on the way in which the success of the European enterprise would lead to a transfer of loyalty to and acceptance of the Community institutions rather than towards the fundamental issue of whether democratic controls in the more normal sense of the term should form an important part of the Community order.

The same sense of legitimacy and democracy can be seen in the work of the neofunctionalists. Legitimacy was conceived of once again largely in terms of outcomes, more specifically increased prosperity. This is exemplified by the work of Lindberg and Scheingold. ${ }^{15}$ Economic determinism lay at the heart of their approach to integration. ${ }^{16}$ They explicitly addressed the tension between the technocratic nature of the Community and its legitimacy, and acknowledged that without effective democratic control, the legitimacy of the Community institutions would be imperiled. ${ }^{17}$ Their response was telling: legitimacy was secured because of the very gains which technocracy secured, notwithstanding the diminution this could entail for the role or powers of elected bodies. Legitimacy and technocracy could therefore exist in perfect harmony, with the former drawing its succor and content from the increased prosperity provided

\footnotetext{
15. See generally LINDBERG, EUROPE'S WOULD-BE POLITY, supra note 3.

16. Id. at 260.

17. Id. at 267.
} 
by the latter. The role to be accorded to democracy itself was perforce limited, and strikingly similar to that which we identified in Monnet's vision. The neofunctionalist focus was directed towards the calculation of the degree of loyalty which people might display towards the Community, ${ }^{18}$ and more specifically to quantification of the requisite "permissive consensus" which must exist in order to enable the technocratic elite to get on with their tasks.

The theory explaining the moderation that seemed to accompany technocratic trends is directly related to the changing life styles and values that we associated with mass consumption. The idea is that increasing affluence stoked by new technology and more aggressive business practices nurture a more benign environment, sublimating social cleavage in an increasingly successful quest for material goods and dissolving political conflict in a consensus of apathy. Control of the government ... [is] important only when a change in governments portends significant changes in policies. In other words, they matter only when the parties perceive significant deprivations or rewards as the stakes of the political game. In pluralistic political systems ... social and political citizenship is assured and most significant groups can count on a slice of the expanding pie. Indeed, the major problem becomes one of maximizing wealth-clearly a question for the experts, the technocrats. ${ }^{19}$

\section{B. Political Stagnation, Institutional Development and the Shifting Institutional Balance}

The original compact underpinning the Rome Treaty came under strain beginning in the mid-1960s. Indeed, the period between 1973 and 1983 has been described as the "stagnant decade". ${ }^{20}$ The 1973 Israeli-Arab war was followed by the oil crisis, recession, and monetary instability. This had far-

\footnotetext{
18. Id., ch. 8 .

19. Id. at. 268-69.

20. See, e.g., Keith Middlemas, Orchestrating Europe: The Informal Polmics of the EUROPEAN UNION 1973-1995, at 73 (1995).
} 
reaching consequences for the Member States. There was a shift in concern from full employment to inflation, a relative prioritization of finance over trade, and the resurgence of protective nationalism. ${ }^{21}$ The pervasive mood in the Community institutions was one of gloom. Social measures, such as directives on codetermination and worker consultation, were rejected by the Council, and many other measures were stalled, awaiting a Council decision. It was the tension between Council and Commission, latent since 1965, which produced this "condition of immobility." 22 The OPEC oil decision at the end of the 1970 s pushed oil prices to over twenty dollars per barrel, precipitating further recession and national defensiveness. Numerous studies testified to the "Eurosclerosis" which beset the Community during this time, most of which pointed the finger of blame on the difficulties of securing the passage of legislation through the Council. ${ }^{23}$

Institutional developments outside the strict letter of the Treaty reflected this shift to a more intergovernmental perspective. Such developments in relation to a constitutional document or Treaty are common. They cannot be ignored since they have a profound effect on the formal disposition of authority laid down in the original constituent document. This is especially so in relation to the early years of the Community. There were a number of such institutional changes which had a marked effect on the Community's institutional balance, increasing the power of the Council at the expense of the Commission. If they had been declared illegal there would have been a constitutional crisis in the Community, since it was clear that the Member States were unwilling to contemplate decisionmaking on any other terms.

The Luxembourg Accords were one such development. They were the prime example of negative intergovernmentalism: they gave the Member States the power to block measures they disliked when they touched on their vital interests. Statistics as to the number of occasions on which this power was actually used are, of course, only part of the story. The threat of the veto shaped the very policies put forward by the Commission, and shaped also the negotiations concerning them; decisionmaking took place under the shadow of the veto.

21. Id. at 78 .

22. Id. at 90 .

23. See, e.g., Pieter Dankert, Introduction to THE EUROPEAN COMMUNITY: PAST, PRESENT AND FUTURE 3-18 (Loukas Tsoukalis ed., 1983). 
The Council's intergovernmental orientation also had a more positive side. The Luxembourg Accords were fine, if the ultimate objective was to veto a measure, but the Member States also desired more finely tuned tools through which to exercise influence over legislation. The Council attained this increased power through a number of institutional developments.

COREPER, the Committee of Permanent Representatives, was developed into a more sophisticated support structure for the Council. It was COREPER, and the working committees that fed into it, which negotiated the details of draft legislative proposals emanating from the Commission. The existence of this bureaucratic support machinery enabled the Council to confer with the Commission about legislation on more equal terms.

This period also saw the emergence of management and regulatory committees. Article 155 of the Rome Treaty expressly contemplated the delegation of power from the Council to the Commission. The assumption was that Council approval was contained in the initial decision to delegate in a specific subject matter area, and that the empowering regulation would set the parameters within which the Commission would then act. The corollary was that the Commission would then make the detailed implementation rules itself, which would become law without further Council oversight. It rapidly became clear that this distribution of authority was unsatisfactory for the Member States. They wished to have a more institutionalized mechanism through which their views on the detailed norms could be taken into account. This was in part because the Member States might well disagree between themselves about such matters, and in part because they were wary about giving the Commission power to make implementing norms without input and control from the States. The management and regulatory committees were invented to enable the Member States to exert real influence on the rules made pursuant to a delegation of power from Council to Commission. These committees were introduced initially in the agricultural sphere, but spread rapidly to other areas. They were staffed by national technocrats, plus the Commission, and Member State influence was reinforced by the fact that a matter could revert to the Council if the committee failed to support, or disagreed with, a Commission 
proposal. We see here the birth of Comitology, the study of which has become much more sophisticated as of late. ${ }^{24}$

The evolution of what is now known as the European Council was another important feature of this positive intergovernmentalism. It enabled the leaders of the Member States to discuss general issues of Community concern outside the framework of the Council itself. The results of their deliberations were often "binding", in the sense of laying down the parameters of future Community action, whether in relation to the size of the Common Agricultural Policy budget, or the strategy for dealing with a foreign policy crisis. The Commission might be invited to these deliberations, but often it was not. These meetings thereby enabled the Member States to control and shape the general direction of Community policy, free from the constraints of action within the Council itself.

These institutional developments had a marked impact on neofunctionalist explanations about integration. In empirical terms, it was argued that neofunctionalism failed to explain the reality of the Community's actual development. The Luxembourg Crisis of 1965 saw the powerful re-emergence of state interests. The de facto unanimity principle contained in the Luxembourg Accords signaled that Member States were not willing to allow Community development that might be inconsistent with their own perceived vital interests. Decisionmaking for many years thereafter was to be conducted in the shadow of the veto. The Commission had a crisis of self-confidence, reflected in its change in role from emerging government for the Community to a more cautious bureaucracy. ${ }^{25}$ At the state level, many of the predictions of political spillover were proving to be equally precarious. Interest group pressure for greater integration of the kind postulated above was equivocal at best or at worst simply wanting. ${ }^{26}$

Neofunctionalism was also challenged in theoretical terms. The fact that Community integration had not proceeded steadily in the manner predicted by neofunctionalists led to modifications to the theory which rendered it

24. See EU COMmittees: Social Regulation, LAW and Politics (Christina Joerges \& Ellen Vos eds., 1999); see also, DELEGATED LEGISLATION AND THE ROLE OF COMMITTEES IN THE EC (Mads Andenas \& Alexander Turk eds., 2000).

25. See Karlheinz Neunreither, Transformation of a Political Role: Reconsidering the Case of the Commission of the European Communities, 10 J. COMMON MKT. STUD. 233, 243-44 (1972).

26. See GEORGE, supra note 4 , at 41-43. 
increasingly complex and indeterminate. ${ }^{27}$ This in turn made it difficult to conduct any meaningful research, since its theoretical core was insufficiently clear. ${ }^{28}$ The precepts of neofunctionalism were attacked more generally for failure to accord with general themes within international relations, which sought to explain why states engaged in international cooperation. Thus Moravcsik argued that the insistence that integration within the EC should be viewed as sui generis was "based in large part on the a priori expectation that Europe would develop in a federal direction, which led neofunctionalists to stress the uniqueness of its institutional structure, rather than analogies to other forms of interstate co-operation." 29

\section{THE SINGLE EUROPEAN ACT}

\section{A. The SEA and the Reconfiguration of the Community's Institutional Balance}

The ratification of the Maastricht Treaty was, as we shall see later, problematic. However, in many ways, it was the Single European Act 1986 which had a more profound impact on the institutional balance within the Community. This discussion will focus on the principal institutional ramifications of this Treaty reform. These should be seen against the backdrop, discussed above, of increased concern that the Community agenda was not being fulfilled and that decisionmaking was grinding to a halt under the weight of intergovernmentalist pressures. The amendments introduced by the SEA were devised at least in part as a response to these problems. Three such changes were of particular importance.

First, the SEA extended qualified majority voting (QMV) in certain important areas. The most significant amendment was the introduction of Article $95,{ }^{30}$ which allowed measures relating to the completion of the internal market to be enacted by QMV. This was especially notable given that the great

27. Andrew Moravcsik, Preferences and Power in the European Community: A Liberal Intergovernmentalist Approach, 31 J. COMMON MKT. STUD. 473,476 (1993); see also, e.g., the increasingly complex formulations contained in LINDBERG \& SCHEINGOLD, REGIONAL. INTEGRATION, supra note 3.

28. Moravcsik, supra note 27 , at 476.

29. Id. at 477 (emphasis omitted).

30. Previously art. 100(a). 
majority of the measures devised to complete the internal market were enacted pursuant to Article 95 . The shift to QMV was accompanied by a greater reluctance on the part of Member States to allow recourse to the Luxembourg Accords. Qualified majority voting had of course been introduced in certain areas considerably earlier than the SEA, most significantly after the end of the transitional period at the inception of the Community. The shift to QMV was indeed one of the reasons for the crisis that led to the Luxembourg Accords themselves. They testified to the unwillingness of Member States to be bound by decisions which they did not assent to. The de facto unanimity principle enshrined in the Accords served to negate in real terms much of the impact of the earlier changes in the Council's voting rules.

The introduction of QMV in areas such as Article 95, coupled with a greater reluctance to allow use of the Luxembourg Accords, had a real impact on Council decisionmaking. Though efforts would of course be made to ensure consensus wherever possible within the Council, ${ }^{31}$ voting would nonetheless be conducted on the assumption that states really could be subjected to measures on which they were outvoted. The advent and use of QMV post- 1986 made it more necessary than ever for the states to pay close attention to the measure on which they were to vote. This further increased the role played by COREPER and the working groups which fed into it, since it was COREPER which would engage in the detailed negotiations on draft measures with the Commission. The impact of such measures was moreover enhanced by the direct effect doctrine, ${ }^{32}$ which allowed individuals to derive rights from Community norms provided that certain conditions were met. In this sense the Member States came to realize that the norms enacted pursuant to QMV were "for real" within their own national legal orders.

The second major change made by the SEA was that the European Parliament (EP) gained some real power in the legislative process. We have already seen that the EP was accorded scant power in the legislative process prior to the SEA; it only had the right to be consulted and only where the Treaty so provided. While the ECJ did its best to reinforce this right, ${ }^{33}$ it could not make consultation other than it was. The early 1980s saw the EP take matters

31. See William Nicoll, Representing the States, in MAASTRICHT AND BEYOND, BUILDING THE EUROPEAN UNION 190-206 (Andrew Duff et al. eds., 1994).

32. Dankert, supra note 23, at 39-56.

33. See Case 138/79, Roquette Freres v. Council, 7 E.C.R. 3333 (1980). 
into its own hands. Frustrated with its minor role in the Community's affairs, even after it had been directly elected, it proposed major reform. The catalyst for these proposals lay in the meetings of the Crocodile Group, which were developed by the EP itself. ${ }^{34}$ The Draft European Union Treaty of 1984 proposed wholesale institutional and substantive changes. The most relevant for present purposes was that legislative authority was to be divided between the Council and the EP. ${ }^{35}$ This did not prove acceptable to the Member States which were the main players framing the SEA.

The SEA did, however, contain the cooperation procedure. ${ }^{36}$ This procedure was meager when viewed against the EP's aspirations in its Draft Treaty. The Member States might have thought that it was just a sop to the EP that would lead to no great alteration in the status quo ante, but that prediction proved to be wrong. The cooperation procedure represented, in the words of Westlake, "a major constitutional innovation in the Community system." applied to Community legislation made under a number of articles, none more important than Article 95, used for single market legislation. The Commission realized that it would have to manage the legislative process more actively to ensure that legislation was not stalled or delayed. It understood that the EP constituted a new player in its own right. Legislation would have to be drafted with one eye on what would be acceptable to the EP and the other on what would pass muster in the Council. The Member States in the Council now had to cope with QMV in tandem with the increased role accorded to the EP under the cooperation procedure. The Council could, to be sure, still prevent the passage of legislation of which it disapproved, but the control that individual Member States wielded over the legislative process was nonetheless diminished. If, as was often the case, the Member States individually and collectively desired that a measure be enacted, they would have to take account of amendments suggested by the EP, or risk the measure failing through a combination of opposition from the EP plus one state in the Council.

The third important change in the Community's institutional balance resulting from the SEA was the formal legitimation of the committee procedure.

34. See Francesco Capotori ET. AL., The EuRopean Union TREATY, COMMENTARy ON THE DRAFT ADOPTED BY THE EUROPEAN PARLIAMENT 11-12 (1986).

35. Draft Treaty on European Union, art. 36 reprinted in CAPOTORI, supra note 34, at 145.

36. Id., art. 252.

37. Martin Westlake, The COMmission and the PaRliament: PaRTNers and RIVALS IN the EUROPEAN POLICY-MAKING PROCESS 37 (1994). 
We have already seen the rationale for the invention of management and regulatory committees. The SEA placed these on a firmer footing by modifying what was then Article 145, now 202, to make clear that the Council could impose certain requirements with respect to powers delegated by it to the Commission. While the passage of the SEA formally legitimated the committee structure, it also, paradoxically or not, gave rise to greater substantive concerns over what became known as Comitology. The reasons resided in the very substance of the SEA itself. The single market program, coupled with the new approach to harmonization, entailed increased use of the committee system to devise technical standards, health and safety rules and the like. ${ }^{38}$ The EP became concerned with its exclusion from this process, dominated as it is by national technocrats acting in conjunction with the Commission.

This period also saw important decisions by the ECJ, which affected the institutional balance within the Community, more specifically the position of the EP within that balance. In Les Verts, ${ }^{39}$ the ECJ held that the acts of the EP were amenable to judicial review. Though significant in and of itself, it was all the more so given that the subject matter of the dispute concerned the manner of allocating funds for fighting elections. The allegation was that allocations were biased in favor of those parties already represented in the EP. The ECJ's decision that this was amenable to review served to emphasize that the Community was to be open to all shades of political party, and that the democratic regime was not to be structured by the "ins" to exclude the "outs." The Chernobyl case ${ }^{41}$ saw the ECJ crafting legal doctrine to reinforce the newly won political prerogatives of the EP. The very fact that the EP had been accorded legislative power by the SEA in certain areas necessarily led to boundary disputes concerning the appropriate Treaty article under which legislation should be enacted. The EP sought to maximize the scope of the cooperation procedure. In the Chernobyl case, it argued that a regulation should have been enacted under Article 95, rather than under Article 31 of the Euratom Treaty, which gave it less input into the legislative process. The issue before the Court was the status of the EP in any such action for judicial review,

38. See infra notes $132-41$ and accompanying text.

39. Case 294/83, Parti ecologiste 'Les Verts' v. Parliament, 1986 E.C.R. 1339

40. See generally JOHN HART ELY, DEMOCRACY AND DISTRUST: A THEORY OF JUDICIAL REVIEW (1990).

41. Case C-70/88, Parliament v. Council, 1990 E.C.R. I-2041. 
since at that time it was not listed among the privileged applicants for the purpose of judicial review under what was Article 173. The Court found for the EP. While its judgment has been criticized, ${ }^{42}$ this critique is largely unfounded. Courts entrusted with the construction of constitutional documents or Treaties will often have recourse to background principles when interpreting the letter of the document. In the instant case, the ECJ acknowledged that the EP was not a privileged applicant for the purposes of judicial review. It also acknowledged, contrary to its own earlier opinion, ${ }^{43}$ that the indirect methods of protecting the EP's legislative prerogatives were imperfect. It then had regard for the principle of institutional balance that underpinned the distribution of power in the Community. The EP's prerogatives were "one of the elements of the institutional balance created by the Treaties, ${ }^{, 44}$ the observance of which had to be ensured by the Court itself. The absence in the Treaties of any provision allowing the Parliament to seek annulment was a procedural gap, but it could not "prevail over the fundamental interest in the maintenance and observance of the institutional balance laid down in the Treaties." ${ }^{, 45}$ The EP could therefore seek review to protect its own prerogatives, which included its participation in the legislative process. ${ }^{46}$

\section{B. The SEA and the Reconceptualization of Integration Theory}

The limitations of neofunctionalism were, as seen above, already noted by the late 1960s. Criticism of the doctrine mounted in the years which followed, but there was no new theory of integration to replace it. It was almost as if the Euro-sclerosis which beset the Community in the 1970s cast a shadow over any novel attempt to theorize about the patterns of integration, with the vagaries of real life proving too complex and uncertain to fit into any meaningful theory at all. The failure of neofunctionalism to explain the nature of the Community's development, the intergovernmental developments outside the strict letter of the Treaty considered above, and a view as to the forces which shaped the SEA

42. See Trevor C. Hartley, Constitutional Problems of the European UNION 35-36 (1999).

43. Case 302/87, Parliament v. Council, 1988 E.C.R. 5615.

44. Parliament v. Council, 1990 E.C.R. at I-2042.

45. Id. at I-2041.

46. See Joseph Weiler, Pride and Prejudice: Parliament v. Council, 14 EUR. L. REV. 334, 345 (1989); G. Bebr, The Standing of the European Parliament in the Community System of Legal Remedies: A Thorny Jurisprudential Development, 10 Y.B. EUR. L. 171 (1990); Kiernan Bradley, Sense and Sensibility: Parliament v. Council Continued, 16 EUR. L. REV. 245, 251-54 (1989). 
itself, ${ }^{47}$ were the foundations for an alternative theory known as liberal intergovernmentalism. Andrew Moravcsik has produced the fullest and most elegant version of this theory. ${ }^{48}$

Moravcsik's thesis is rooted firmly in the current general tradition of international relations theory. This theory is itself grounded on certain key assumptions derived from economics, and more specifically from the literature on public choice and the logic of collective action. The core of liberal intergovernmentalism is composed of three essential elements, "the assumption of rational state behavior, a liberal theory of national preference formation, and an intergovernmentalist analysis of interstate negotiation." ${ }^{49}$ The assumption of rational state behavior provides a general framework of analysis, within which the costs and benefits of economic interdependence are the primary determinants of national preferences. The "relative intensity of national preferences, the existence of alternative coalitions, and the opportunity for issue linkages provide the basis for an intergovernmental analysis of the resolution of distributional conflicts among governments." ${ }^{50}$ Consistent with its economic underpinnings, liberal intergovernmentalism postulates integration being determined by demand and supply.

The demand for integration is a function of domestic preference formation, through which the benefits of policy coordination at the European level are identified. Groups within society articulate preferences and governments, which then aggregate and give effect to them. ${ }^{51}$ In this sense, liberal intergovernmentalists conceive of the relationship between society and government as one of principal and agent, in which it is societal principals who delegate power to government agents. ${ }^{52}$ The primary objective of governments is to retain power, and this therefore requires them to secure the support of societal actors by promising to attain the preferences that they have articulated.

47. See Andrew Moravcsik, Negotiating the Single European Act: National Interests and Conventional Stagecraft in the European Community, 45 INT'L ORG. 19 (1991).

48. Moravcsik, supra note 27; ANDREW MORAVCSIK, THE CHOICE FOR EUROPE: SOCIAL PURPOSE AND STATE POWER FROM MESSINA TO MAASTRICHT l-18 (1998) [hereinafter MORAVCSIK, THE CHOICE FOR EUROPE]; ANDREW MORAVCSIK, NATIONAL PREFERENCE FORMATION AND INTERSTATE BARGAINING IN THE EUROPEAN COMMUNITY 1955-1986 (1992).

49. Moravcsik, supra note 27, at 480; MORAVCSIK, THE CHOICE FOR EUROPE, supra note 48, at 18-23.

50. Moravcsik, supra note 27 , at $480-81$.

51. There is no assumption that literally all groups within society will be in favor of integration in order to remove such extemalities. To the contrary it is readily accepted that there will be distributional consequences of policy co-ordination which might disadvantage certain groups and hence generate opposition from them.

52. Moravcsik, supra note 27 , at 483. 
The benefits to be gained from coordination, and hence the preferences for some degree of integration, can vary. Liberal theories of interdependence do however make certain more general empirical assumptions about the reasons why people might be in favor of international policy coordination. Such theories are based on economic interdependence, in the sense that "increasing transborder flows of goods, services, factors or pollutants create 'international policy externalities' among nations which in turn create incentives for policy coordination." ${ }^{53}$ International policy externalities arise where the policies of one government create costs and benefits for politically significant social groups outside its national jurisdiction. Where the achievement of domestic governmental goals depends on the policies of its foreign counterparts, national policies are interdependent and policy externalities arise.

The supply of integration is a function of inter-state bargaining and interstate strategic interaction. For liberal intergovernmentalism the shape of domestic preferences defines "a 'bargaining space' of potentially viable agreements, each of which generates gains for one or more participants." Governments that are bent on collective action must therefore choose one such agreement, and negotiation is the medium through which such collective choice is made. Yet negotiations themselves are not cost free, and governments will weigh the potential gains from collective action against the costs of negotiation and the diminution in the scope of autonomous action which any such successful agreement will entail.

Liberal intergovernmentalism also provides an explanation as to why such integration should be pursued through a supranational institution. Once again it is economics which provides the foundations for liberal intergovernmentalist thought in this respect. The primary rationale for the existence of such supranational institutions is efficiency. Regime theory regards such institutions as a mechanism for the reduction of transaction costs. Constructing individual ad hoc bargains between states can be costly and inefficient. This problem is obviated by the creation of a supranational structure such as the EC, which provides a stable institutional setting for the resolution of the inter-state bargains considered above. ${ }^{55}$ Moravcsik builds on these foundations in order to

53. Id. at 485; MORAVCSIK, THE CHOICE FOR EUROPE, supra note 48, at 35 .

54. Moravesik, supra note 27, at 497.

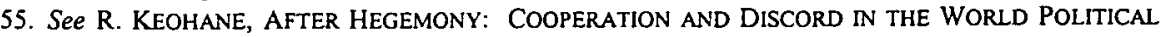
ECONOMY (1984); JAMES M. BUCHANAN \& GORdON TUllock, THE CALCUluS OF CONSENT: LogiCAL. Foundations of CONSTITUTIONAL DemocraCy (Ann Arbor Paperbacks, 1965) (1962). 
explain the novel features of the Community's institutional structure, such as the powers possessed by the Commission and the ECJ. He acknowledges that states have both pooled their sovereignty, through qualified majority voting, and delegated power to semi-autonomous institutions. The explanation for this is derived explicitly from public choice theory.

Following public choice analyses of domestic constitutional choice, intergovernmentalist theory views the decision to adopt qualified majority voting or delegation to common institutions as the result of a cost-benefit analysis of the stream of future substantive decisions expected to follow from alternative institutional designs. For individual Member States carrying out such a cost-benefit calculation, the decision to delegate or pool sovereignty signals the willingness of national governments to accept an increased risk of being outvoted or overruled on any individual issue in exchange for more efficient collective decision-making on average. . . . Compared to unanimity voting, delegation and pooling of sovereignty are more efficient, but less controlled forms of collective decision-making. Of the two delegation involves greater political risk and more efficient decision-making, while pooling through qualified majority voting involves less risk, but correspondingly less efficiency. ${ }^{56}$

The essence of the liberal intergovernmental model should not be lost sight of. The central message is that states are the driving forces behind integration, and that supranational actors are there largely at their behest with little independent impact on the pace of integration. ${ }^{57}$

This picture of the integration process has been contested empirically and normatively. It cannot be examined in detail here, but it is important to be aware of the principal aspects of the critique. The empirical claim that states are the driving force behind integration has been contested by advocates of new institutionalism and multi-level governance, and from integration theories that

56. Moravcsik, supra note 27, at 509-10; see also MORAVCSIK, THE CHOICE FOR EUROPE, supra note 48, at $67-77$.

57. MORAVCSIK, The ChOICE FOR EUROPE, supra note 48, at 52-66. 
draw on them. These will be examined in the next section. ${ }^{58}$ Suffice it to say for the present that opponents of liberal intergovernmentalism conceive of the integration process, especially that which takes place outside major Treaty revisions, as more complex. It is accepted that states are important in this process. The picture of integration which emerges from new institutionalist thinking, and multi-level governance, is nonetheless very different, with a plethora of actors having an important impact on Community development. Moreover, it should be recognized that the very identification of national preferences, so central to state-centric theory, can itself be problematic. ${ }^{59}$

A second aspect of the empirical critique is related to, but distinct from, the first. We have seen that liberal intergovernmentalist thought came to the fore in the 1980 s, in part as a response to the perceived failings of neofunctionalism, in part because of intergovernmentalist developments outside the strict letter of the Treaty, and in part because of the application of general international relations theory to the Community. The paradox is nonetheless that it was the passage of the SEA which served to diffuse power and undermine the assumption that states were the players in the integration process. The extension of QMV reduced individual state control over decisionmaking. The increase in the power of the EP diminished state control over the course of events. It constituted, when viewed against the premises of intergovernmentalism, a "loose cannon," in that the way in which it would use its powers might not be readily predictable. The single market enterprise, which was the substantive raison d'être of the SEA, led to increased use of Comitology, with the correlative bypassing of state democracy as national technocrats negotiated directly with their Community counterparts. The state-centric view of the world was further weakened by the pattern of Community administration. Many important policies, such as agriculture and the structural funds, were administered jointly between the Commission and national officials. This pattern of shared administration was to be increasingly supplemented by direct administration, where the Commission would be accorded power to take forward policy initiatives, often through the use of private contractors, without a formal link with national bureaucracies. ${ }^{60}$ It should not be forgotten that the SEA revitalized the Community and the role of the Commission therein. It was

58. See infra notes 86-102 and accompanying text.

59. MIDDLEMAS, supra note 20, at 115-35.

60. See infra Part V. 
the Commission which was the driving force behind the single market project, the overall legislative agenda, and the shaping of particular policies.

The premises underlying liberal intergovernmentalism have also been contested from a normative perspective. The rationale for the $\mathrm{EP}$ is problematic for those of this persuasion. So, too, is the conception of democracy and constitutionalism which does and should pertain within the Community. ${ }^{61}$

The normative challenges to state-centric theories, such as liberal intergovernmentalism, have come more generally from the development within politics known as the new institutionalism. ${ }^{62}$ The foundations for new institutionalism were laid by March and Olsen. ${ }^{63}$ They are critical of what they characterize as the dominant themes in the politics' literature since the 1950s: contextualism, reductionism, utilitarianism, instrumentalism, and functionalism. ${ }^{64}$ Contextualism captures the idea that politics is not to be differentiated from the remainder of society. While this is to some extent true, March and Olsen lament the fact that whereas historically political scientists treated the state as an independent factor, which was important to the ordering of collective life, most modern political scientists do not do so. Reductionism is expressive of the modern tendency to assume that political phenomena are best understood as the aggregate consequences of individual or group behavior, acting so as to maximize their exogenous preferences. This was by way of contrast to older modes of thinking which "treated political institutions as determining, ordering, or modifying individual motives, and as acting autonomously in terms of institutional interests." ${ }^{65}$ For the authors, utilitarianism is indicative of the related inclination within modern political science to see action as stemming from calculated self-interest. The pre-

61. Paul Craig, The Nature of the Community: Integration, Democracy and Legitimacy, in THE Evolution of EU LAW 11-16 (Paul Craig \& Gráinne de Búrca eds., 1998).

62. The resurgence of interest in institutionalism can be detected in a number of different disciplines, including political science, economics, international relations, and sociology. See Paul J. DiMaggio \& Walter W. Powell, Introduction to THE NEW INSTITUTIONALISM IN ORGANIZATIONAL ANALYSIS, 1, 1-4 (Walter W. Powell \& Paul J. DiMaggio, eds., 1991). This should not, however, lead one to think that all those who go under the mantle of institutionalism subscribe to the same set of beliefs. Rational choice institutionalists may well have modified some of the premises on which rational choice theory itself is based, but they also still accept many others. To assume that, for example, rational choice institutionalists are particularly close to either the normative institutionalism of March and Olsen or historical institutionalism would therefore be mistaken.

63. See JAMES G. MARCH \& JOHAN P. OLSEN, REDISCOVERING INSTITUTIONS: THE ORGANIZATIONAL BASIS OF POLITICS (1989).

64. See id. at 2-8.

65. Id. at 4 . 
eminent "vision of human behaviour is a vision of choice," with life being characterized as "deliberate decision making." 66 This is contrasted with an historical tradition in which "political behavior was embedded in an institutional structure of rules, norms, expectations, and traditions that severely limited the free play of individual will and calculation." ${ }^{167}$ Instrumentalism is used to capture the idea that current political science has given primacy to outcomes, expressed in terms of resource allocation. This is at the expense of the historical tradition which "portrayed political decision making primarily as a process for developing a sense of purpose, direction, identity, and belonging," and as "a vehicle for educating citizens and improving cultural values."68 Functionalism for March and Olsen signifies the tendency to regard history as an efficient mechanism for the attainment of some equilibrium, as exemplified by the primacy accorded to the idea of optimality. This was contrary to the earlier approach which placed emphasis on the singular or unique within a particular historical context.

New institutionalism has been employed specifically within the Community context. It has generated a number of interesting studies which may differ in detail, but which share one general feature. Present in the studies is the tendency to treat integration in less state-centered, monistic terms than liberal intergovernmentalists, and to emphasize the importance of the supranational institutions themselves in the pattern of Community development. ${ }^{69}$ This accords with the central thrust of new institutionalist thinking:

Without denying the importance of both the social context of politics and the motives of individual actors . . institutional

66. Id. at 5 .

67. Id.

68. Id. at 6.

69. See, e.g., Kenneth A. Armstrong, New Institutionalism and European Union Legal Studies, in LAWMAKING IN THE EUROPEAN UNION 89 (Paul Craig \& Carol Harlow eds., 1998); Kenneth A. Armstrong, Regulating the Free Movement of Goods: Institutions and Institutional Change, in NEW LEGAL DYNAMICS OF EUROPEAN UNION 165 (Jo Shaw \& Gillian Moore eds., 1995); Simon J. Bulmer, The Governance of the European Union: A New Institutionalist Approach, 13 J. PUB. POL'Y 351 (1993); Markus Jachtenfuchs, Theoretical Perspectives on European Governance, 1 EUR. L. J. 115 (1995); Paul Pierson, The Path to European Integration: A Historical Institutionalist Analysis, 29 COMP. POL. STUD. 123 (1996); Thomas Risse-Kappen, Exploring the Nature of the Beast: International Relations Theory and Comparative Policy Analysis Meet the European Union, 34 J. COMMON MKT. STUD. 53 (1996); Daniel Wincott, Institutional Interaction and European Integration: Towards an Everyday Critique of Liberal Intergovernmentalism, $33 \mathrm{~J}$. COMMON MKT. STUD. 597 (1995); Daniel Wincott, Political Theory, Law, and European Union, in NEW LEGAL DYNAMICS OF EUROPEAN UNION 293 (Jo Shaw \& Gillian More eds., 1995). 
analysis posits a more independent role for political institutions. The state is not only affected by society but also affects it. . . Political democracy depends not only on economic and social conditions but also on the design of political institutions. Bureaucratic agencies, legislative committees, and appellate courts are arenas for contending social forces, but they are also collections of standard operating procedures and structures that define and defend values, norms, interests, identities, and beliefs. ${ }^{70}$

\section{FROM MAASTRICHT TO AMSTERDAM}

\section{A. Maastricht: The Shifting Institutional Balance}

The Treaty on European Union (TEU) was signed by the Member States in February 1992 and entered into force in November 1993. It was preceded by two Intergovernmental Conferences (IGCs), one dealing with economic and monetary union, the other with aspects of political integration. The political forces that shaped the TEU were as complex as the resulting Treaty itself. ${ }^{71}$ This very complexity served to render conclusions about the TEU contentious. Commentators differed as to the overall impact of the Treaty on the nature of the Community project and the institutional balance encapsulated therein.

In structural terms, the major innovation of the TEU was the creation of the three pillar structure. The Community Treaties constituted the first pillar, Common Foreign and Security Policy (CFSP) the second pillar, and Justice and Home Affairs (JHA) the third. The details of decisionmaking under pillars two and three can be found elsewhere. ${ }^{72}$ Suffice it to say for the present that the principal difference was that Member States retained much greater control over decisionmaking in these areas than under pillar one. Decisions made regarding

70. MARCH \& OLSEN, supra note 63, at 17 (intemal citations omitted).

71. See MIDDLEMAS, supra note 20, at 156-206; MORAVCSIK, THE CHOICE FOR EUROPE, supra note 48, at 379-471; HuGO YOUNG, THIS BLESSED PLOT: BRITAIN AND EUROPE FROM CHURCHILL TO BLAIR 375-411 (1998).

72. See Paul Craig \& GránNe de Búrca, Eu law: Text, Cases, and Materials 3-53 (3rd. ed. 2002). 
CFSP and JHA were more intergovernmental in nature, with the Community institutions having far less of a role within these areas.

In political terms the second of the IGCs which led to the TEU had its political origins in Member State concerns over foreign policy and the threat to national security represented by cross-border crime, illicit drugs, and the like. The imminent breakup of Yugoslavia, and the link between foreign policy and security, served to bring defense onto the IGC's agenda. It should be remembered that the very architectural terminology of the pillar structure was vigorously contested at the IGC. The majority of the Member States, together with the Commission and the EP, favored an arboreal metaphor: the new Treaty would be conceived as the trunk, with the three elements constituting the branches. Opposition from Britain and France convinced the Luxembourg Presidency that this would not prove acceptable, and that the temple model would have to be adopted instead. ${ }^{73}$

Differing conceptual explanations for the emergence of the three-pillar structure have been given. Weiler has argued that they can best be explained through a consociational model. ${ }^{74}$ In pluralistic societies functional stability is normally secured by cross-cutting cleavages. This could not, however, explain stability in those societies characterized by cleavages which reinforced each other, leading to very divisive conceptions of the public good. Some countries displayed such reinforcing social cleavage, and yet were stable nonetheless. Consociational theory sought to explain this through the behavior of a cartel of elites, which rendered the system both functional and stable. ${ }^{75}$ The consociational model is said to correspond to the international dimension of EU governance, since we have a transnational polity which is sharply segmented by its Member States, which does none the less manage to create structures to deal with problems of common concern. ${ }^{76}$

There is another possible view: that the states wished to have some degree of international cooperation in these areas, but were not ready for the application of the full supranational machinery which operates in pillar one. This explanation is also explicitly acknowledged by Weiler. ${ }^{77}$ This view is not,

73. See MIDDLEMAS, supra note 20 , at 192.

74. See J.H.H. Weiler et al., European Democracy and its Critique, in THE CRISIS OF REPRESENTATION IN EUROPE 4, 28-31 (Jack Hayward ed., 1995).

75. Id. at 30 .

76. Id. at 29.

77. Id. at 30 . 
however, dependent upon the existence of sharply segmented cleavages between the states. There will of course be differences of view on the matters covered by the second and third pillars, but there is no reason to think that these differences will necessarily be more severe than those which exist on pillar one issues. Nor is there any reason to believe that such cleavages should be reinforcing across different divides, thereby giving society its segmented quality. It is by no means clear that the differences which exist between states on pillar two and three issues are reinforcing in this sense. The rationale for choosing intergovernmental over supranational machinery is, rather, that the states believed that some form of cooperation would be beneficial for reasons of the kind articulated by liberal intergovernmentalists. The sensitive nature of the subject matter, touching closely at the heart of national sovereignty, meant that states preferred the "default position" of intergovernmentalism, thereby retaining maximum control in their own hands.

A further important institutional feature of the TEU was the recognition given to the European Council. We have already seen how the meetings of the heads of state developed outside the strict letter of the original Treaty. The first mention of the European Council within a Treaty came in the SEA. The TEU accorded it greater formality, ${ }^{78}$ by stating that the European Council, meeting at least twice a year, should provide the Union with the necessary impetus for its development, and define its general political guidelines. The paucity of Treaty references to the European Council should not lead one to doubt its importance. The reality is that no developments of genuine importance for the Community's internal structure, or for its external relations, will occur without having passed through at least one summit meeting. It plays a central role in setting the pace and shape of Community policy, establishing the parameters within which the other institutions will then operate. Major changes to the Treaties will result from the IGCs, which will normally be created as a result of meetings in the European Council. It will be this body which will decide on the pace of enlargement. It has produced significant constitutional initiatives which affect the operation of the Community, such as the Inter-Institutional Agreement on Subsidiarity and the Declaration on Democracy, Transparency, and Subsidiarity, which were made at, or on the fringes of, such European Council

78. TREATY ON EUROPEAN UNION, Oct. 11, 1997, O.J. (C 340) 145 (1997), art. 4, available at http://www.europa.eu.int [hereinafter TREATY ON EUROPEAN UNION] (original Treaty on European Union, Feb. 7, 1992, O.J. (C 191) l (1992)). 
meetings. The state of the European economy will be regularly discussed at such summits, and priorities accorded to certain types of action. The meetings of the heads of state will often be a forum for conflict resolution between the states. External relations form part of the regular agenda.

The relation between the European Council and other Community institutions has itself evolved. Summits held by heads of state were originally viewed with suspicion by bodies such as the Commission, since the meetings were often held in secret and the Commission was normally excluded. Matters are very different today. The Commission President is a member of the European Council, and many of the European Council's initiatives are themselves the result of Commission initiatives. ${ }^{79}$ The President of the European Parliament has, since 1988, addressed a plenary session of the European Council. The European Council is, in the words of Westlake, "no longer an unwelcome guest but a valued colleague."

The TEU also made changes to the institutional balance as it operated directly within the Community pillar. These changes affected the disposition of power between the Community institutions, and between the Community and the Member States. The principal modification in the interinstitutional balance of power was the creation of the codecision procedure. This increased the role of the EP in the legislative process, a fact which was underlined by its application to important areas such as the internal market. ${ }^{81}$ The EP's power over the appointment of the Commission was enhanced, and an Ombudsman was established. Subsidiarity was included to address the balance of power between the Community and the Member States. ${ }^{82}$ The word "federal" had been excised from the draft Treaty, ending up on the cutting room floor; the TEU nonetheless still spoke of an ever closer union. ${ }^{83}$ Subsidiarity was therefore intended to be protection for state interests against the exercise of Community power. This was felt to be all the more important, given that the sphere of Community competence was expanded by the TEU itself. The EC gained important new powers over economic and monetary policy, as a precursor to monetary union. The EC was also accorded new or modified competence over areas as diverse as culture, public health, Trans-European

79. See Martin Westlake, The Council of the EuRopean Union at 25-26, (1995).

80. Id. at 31 .

81. See TREATY ON EUROPEAN UNION art. 95.

82. Id., art. 5 .

83. Id., art. 1 . 
networks, consumer protection, and development cooperation. In formal legal terms, subsidiarity was to prove problematic insofar as it was intended to be some panacea for the protection of state power. It only applied to areas which were not within the Community's "exclusive competence," and there was no definition of this elusive phrase. ${ }^{84}$ Moreover, the ECJ signaled that it would not lightly hold that Community action violated the subsidiarity principle. ${ }^{85}$ The principle has, however, had some impact on the incidence and type of Community measure adopted.

\section{B. Integration, Multilevel Governance, and the Challenge to Liberal Intergovernmentalism}

Liberal intergovernmentalism was itself but part of a broader state-centric view, which saw the Community not as a challenge to the nation state, but as a mechanism for strengthening state sovereignty. Supranational institutions served the wishes of national executives, enabling them to attain policy goals that would be beneficial to their countries and that could not be obtained by independent action. ${ }^{86}$ The new institutionalist thinking considered above has challenged this state-centric view. It has also been challenged post-TEU by those who viewed the Community more in terms of multilevel governance.

The essence of this theory, as presented by Marks, Hooghe, and Blank, is that integration is a "polity creating process in which authority and policymaking are shared across multiple levels of government - subnational, national and supranational. ${ }^{187}$ While national governments are major players in this

84. Compare A. G. Toth, A Legal Analysis of Subsidiarity, in LEGAL ISSUES OF THE MAASTRICHT TREATY 37, 39 (David O'Keefe \& Patrick M. Twomey eds.,1994) with Josephine Steiner, Subsidiarity Under the Maastricht Treaty, in LEGAL ISSUES OF THE MAASTRICHT TREATY, supra, at 49, 49-64.

85. See, e.g., Case C-84/94, United Kingdom v. Council 1996 E.C.R. I-5755; Case C-233/94, Germany v. Parliament \& Council 1997 E.C.R. I-2406.

86. See, e.g., Alan S. Milward, The European Rescue of the Nation-STAte 116 (1992); Alan S. Milward \& V Sorensen, Independence or Integration? A National Choice, in THE FRONTIER OF NATIONAL SOVEREIGNTY: HISTORY AND ThEORY, 1945-1992, at 1, 18-20 (Alan S. Milward et al. eds., 1993); PAUL TAYLOR, The European Community and the State: Assumptions, Theories and Propositions, 17 REV. OF INT'L STUD. 109 (1991).

87. Gary Marks et al., European Integration from the 1980s: State-Centric v. Multiple-Level Governance, 34 J. COMMON MKT. STUD. 341, 342 (1996); see also, Thomas Risse-Kappen, supra note 69, at 53; Jonathan Golub, State Power and Institutional Influence in European Integration: Lessons from the Packaging Waste Directive, 34 J. COMMON MKT. STUD. 313 (1996); James Caporaso, The European Union and Forms of State: Westphalian, Regulatory or Post-Modern?, 34 J. COMMON MKT. STUD. 29, $44-48$ (1996); Fritz Scharpf, Introduction: The Problem Solving Capacity of Multi-Level Governance, 4 J. EUR. PUB. POL'Y 520 
process, they do not have a monopoly of control. Decisionmaking competences "are shared by actors at different levels rather than monopolized by state executives." ${ }^{\prime 88}$ Supranational institutions, including the Commission, the EP and the ECJ, "have independent influence in policy-making that cannot be derived from their role as agents of state executives." ${ }^{89}$ Collective decisionmaking at the Community level is perceived as entailing a significant loss of control for state executives. For advocates of multilevel governance, political arenas are interconnected rather than nested. National arenas may be of importance for the formation of state preferences, but the "multi-level model rejects the view that subnational actors are nested exclusively within them." 90 States may play the decisive role in the Treaty making process, but they do not control this process in its entirety, since other players such as the Commission will exert influence.

States do not monopolize links between domestic and European actors, but are among a variety of actors contesting decisions that are made at a variety of levels. In this perspective, complex interrelationships in domestic politics do not stop at the nation-state, but extend to the European level. The separation between domestic and international politics, which lies at the heart of the state-centric model, is rejected by the multi-level governance model. States are an integral and powerful part of the EU, but they no longer provide the sole interface between supranational and subnational arenas, and they share, rather than monopolize, control over many activities that take place in their respective territories. ${ }^{91}$

Proponents of multi-level governance argue that when competence has been transferred to the Community level, there are very real limits to the degree of individual and collective state control over Community decisions. ${ }^{92}$ They contest the liberal intergovernmentalist thesis which rationalized the power of

(1997); Gary Marks \& Doug McAdam, Social Movements and the Changing Structure of Political Opportunity, in GOVERNANCE IN THE EUROPEAN UNION 95-121 (Gary Marks et al. eds., 1996).

88. Marks et al., supra note 87 , at 346.

89. Id.

90. Id.

91. Id. at 346-47.

92. See id. at 350-51. 
the Commission and the ECJ through delegation and agency theory. Instead, they counter that the ability of the principals, the Member States, to control the agents is limited by a range of factors. These include the "multiplicity of principals, the mistrust that exists among them, impediments to coherent principal action, informational asymmetries between principals and agents and by the unintended consequences of institutional change." ${ }^{93}$ While the Council, the European Council, and the EP have all circumscribed the Commission's formal monopoly of legislative initiative, "none can claim that it has reduced the position of the Commission to that of an agent." "shared and contested competence" among the four Community institutions, rather than being monopolized by any one actor. Subnational actors, such as interest groups, will also be of importance in this context. The codecision procedure has moreover transformed the making of legislation from "a simple Council-dominated process into a complex balancing act between Council, Parliament and Commission." "95 The result is that "the Council is locked in a complex relationship of cooperation and contestation with the other two institutions." ${ }^{96}$ A similar pattern can be perceived in the Community's committee system. While Comitology procedures have enabled the states to exert some control over the passage of implementing norms, this is far from proving that states really exercise a monopoly of control in this area. A more realistic assessment sees outcomes resulting from the interaction of the Commission, state technocrats and interest groups. ${ }^{97}$ Numerous Community studies have drawn on multilevel governance and new institutionalism. ${ }^{98}$

Multilevel governance is not in itself a theory of integration, but important work on integration is supportive of its underlying assumptions, and draws also on the tenets of new institutionalism. Stone Sweet, and Sandholtz ${ }^{99}$ have advanced a theory of integration to rival the state-centric view posited by the

93. Id. at 353-54.

94. Id. at 358,361 .

95. Id. at 364 .

96. Id. at 365; see also WESTLAKE, supra note 37; Paul Craig, Democracy and Rule-Making Within the EC: An Empirical and Normative Assessment, 3 EUR. LAW J. 105, 107-09 (1997).

97. Marks et al., supra note 87, at 367-69; . See also, J.H.H. Weiler et al., European Democracy and its Critique, in THE CRISIS OF REPRESENTATION IN EUROPE 32-33 (Jack Hayward ed., 1995); Wolf Sauter \& Ellen Vos, Harmonization Under Community Law: The Comitology Issue, in LAWMAKING IN THE EUROPEAN UNION, supra note 69 , at 169,186 .

98. See supra notes $69,87$.

99. A. Stone Sweet \& W. Sandholtz, European Integration and Supranational Governance, 4 J. EUR. PUB. POL'Y 297 (1997). 
intergovernmentalists. They argue that there is a continuum between pure intergovernmental politics at one end of the spectrum and supranational politics at the other. Where pure intergovernmental politics operate, the states are the central players who will bargain inter se to reach commonly acceptable policies; the EC has only a "passive relevance" in the sense of enhancing the efficiency of such interstate bargains. At the supranational end of the spectrum there will be supranational institutions that are able to constrain the behavior of all actors, including the Member States, within the relevant areas.

A range of factors may affect the shift along the spectrum. Non-state actors who transact across borders will often need, or benefit from, supranational governance in terms of common European rules, standards, and the like. The absence of such rules will be viewed as detrimental because of the increased transaction costs thereby entailed. When their governments are reluctant to move in this direction, the private actors can seek access to supranational organizations such as the Commission and the ECJ. While governments can influence the pace of integration, "they do not drive the process or fully control it," 100 and intergovernmental bargaining, when it occurs, "more often than not is responsive to the interests of a nascent, always developing, transnational society." 101 The location of a policy area at a particular point on the spectrum will then be dependent on the levels of cross-border transactions and the consequential need for supranational coordination within that area. This pattern of integration is reinforced through the progressive institutionalization of changes which have occurred.

Organizations produce and transmit the rules that guide social interaction. They structure access to policy processes, defining political power and privileging some parts of society more than others. As supranational organizations acquire and wield autonomy, they are able to shape not only specific policy outcomes but also the rules that channel policy-making behaviours. As supranational organizations and rules emerge and solidify, they constitute transnational society by establishing bases for interaction and access points for influence. As transnational society endures and expands, the 
organizations and rules that structure behaviours become more deeply rooted as "givens", taken for granted as defining political life. ${ }^{102}$

\section{From Maastricht to Amsterdam: The Emergence of the Legitimacy Discourse}

In the period between Maastricht and Amsterdam, the discourse on legitimacy, as well as democracy, took center stage. ${ }^{103}$ There had, of course, been discussion of these issues prior to the TEU, but this discourse became more central in the Amsterdam IGC. The focus of the debate preceding the Amsterdam Treaty cannot be appreciated without some understanding of the eclectic forces which contributed to it.

The legitimacy of the EU was called into question in straightforward political terms by the difficulties in securing ratification of the TEU within the Member States. The initial Danish "no vote" sent shock waves through the Community. It set off "a train of responses, among parliamentary parties, media, and sections of national public opinion in other nations, which almost wrecked the entire process." ${ }^{\text {"104 }}$ The Community held its breath for the outcome of the French referendum, which was positive, but only by the smallest of margins, 51.05 to 48.95 percent. In the UK, the TEU was debated long and hard, albeit on an implicit incorrect assumption that the national Parliament

102. Id. at 305 .

103. See generally, EUROPEAN IDENTITY AND THE SEARCH FOR LEGITIMACY (Soledad García ed., 1993); THE CRISIS OF REPRESENTATION IN EUROPE (J. Hayward ed., 1995); A CITLZENS' EUROPE: IN SEARCH OF A NEW ORDER (A llan Rosas \& Esko Antola eds., 1995); DEMOCRACY AND CONSTITUTIONAL CULTURE IN THE UNION OF EUROPE (Richard Bellamy et al. eds., 1995); THE EUROPEAN UNION: HOW DEMOCRATIC IS IT? (Svein S. Andersen \& Kjell A. Eliassen eds., 1996); CONSTITUTIONALISM IN TRANSFORMATION: EUROPEAN AND THEORETICAL PERSPECTIVES (Richard Bellamy \& Dario Castiglione eds., 1996); CONSTITUTIONALISM, DEMOCRACY AND SOVEREIGNTY: AMERICAN AND EUROPEAN PERSPECTIVES (Richard Bellamy ed., 1996); CONSTITUTIONAL DIMENSIONS OF EUROPEAN ECONOMIC INTEGRATION (Francis Snyder ed., 1996); EUROPE: THE IMPOSSIBle Status QUO (Renaud Dehousse ed., 1997); DEIRDRE CURTIN, POSTNATIONAL DEMOCRACY: THE EUROPEAN UNION IN SEARCH OF A POLITICAL PHILOSOPHY (1997); LAWMAKING IN THE EUROPEAN UNION, supra note 69; J.H.H. WEILER, THE CONSTITUTION OF EUROPE (1999); DEMOCRATIZING THE EUROPEAN UNION: ISSUES FOR THE TWENTY-FIRST CENTURY (Catherine Hoskyns \& Michael Newman eds., 2000); BRIGID LAFFAN ET AL., EUROPE'S EXPERIMENTAL UNION: RETHINKING INTEGRATION (2000); JUDGE G.F. MANCINI, DEMOCRACY AND CONSTITUTIONALISM IN THE EUROPEAN UNION (2000); EUROPEAN INTEGRATION AFTER AMSTERDAM: INSTITUTIONAL DYNAMICS AND PROSPECTS FOR DEMOCRACY (Karlheinz Neunreither \& Antje Wiener eds., 2000); ROMANO PRODI, EUROPE AS I SEE IT (Allan Cameron, trans., 2000).

104. MIDDLEMAS, supra note 20, at 197. 
could, if it so wished, modify particular terms of the Treaty presented to it. The fight over the Treaty was not confined to the political sphere, but spilled over into the judicial arena. ${ }^{105}$ It was in the legal arena that the constitutionality of ratification was fought out in Germany. While the Federal Constitutional Court gave the green light for Germany's ratification, it sent powerful signals as to the limits of Community legislative and judicial competence. ${ }^{106}$ It would be wrong to believe that the same forces were at work in these and other states which experienced difficulties over ratification of the TEU. Differing factors shaped the debate and were accorded prominence in, for example, France, Germany, and the UK. This very fact served to enhance the problematic status of the EU among the peoples of Europe in the post-TEU world.

The political challenge was accompanied by literature which questioned sharply the legitimacy of the TEU from a more constitutional perspective. Curtin's well known article ${ }^{107}$ characterized the settlement reached in the TEU as giving rise to a Union of "bits and pieces," which placed in danger the very uniformity of Community law. It raised the specter of constitutional chaos threatening to undermine the cohesion of a legal system which had been built up over the preceding years.

There was increased discussion as to the institutional legitimacy of the Community order, notwithstanding the extra power accorded to the EP through the codecision procedure. This shaded into a growing body of literature questioning the allocation of power within the Community, and analyzing the "democracy deficit" which was said to exist therein. This discourse was given added force by the increase in the scope of Community competence postMaastricht.

The legitimacy of the EU was also called into question on what were in effect more traditional rule of law grounds, a principal tenet of which is that laws should be clear in order to guide conduct. The settlement embodied in the TEU was many things, but clear it was not. The criteria for the making of legislation within the Community pillar were complex, and this problem was exacerbated by the plethora of voting rules in the Council. Decisionmaking

105. See Richard Rawlings, Legal Politics: The United Kingdom and Ratification of the Treaty on European Union, PUB. LAW 254, 367 (1994).

106. See Case 2 BvR 2134/92 \& 2159/2, Brunner v. The European Union Treaty I C.M.L.R. 57 (BVerfGE 1994) (F.R.G.).

107. See Deirdre Curtin, The Constitutional Structure of the Union: A Europe of Bits and Pieces, 30 COMMON MKT. L. REV. 17 (1993). 
under pillars two and three had its own terminology, which could be understood only by those versed in these arcane matters. The substantive complexity was matched by the variety of systems for numbering the EU and EC provisions. The combination of substantive and numerical intricacy was particularly apparent in the provisions on EMU, which formed the economic comerstone of the TEU.

\section{THE AMSTERDAM TREATY: CONSOLIDATION AND CHANGE}

\section{A. The Discourse Concerning Legitimacy, Democracy, and Institutional Balance Leading to Amsterdam}

It was, in the light of the above, unsurprising that issues of legitimacy, democracy, and institutional balance should loom large in the IGC discussions leading to the Amsterdam Treaty. ${ }^{108}$ The documents stressed the need to preserve the Community's institutional balance; the retention of the Commission's right of legislative initiative; the simplification of the legislative process; and problems flowing from pillars two and three.

The desire to preserve institutional balance within the Community was apparent throughout the Report of the Reflection Group. ${ }^{109}$ Institutional reform must observe "the overall institutional balance, in accordance with the specific character of the European Union."110 Democracy was to be thought of in relation to all the Community institutions and the institutional balance which existed between them. The Council argued that "democratic legitimacy must be the expression of the Union's institutional system as a whole," and not merely a concept thought of only in relation to the EP. ${ }^{111}$ The Commission stated that the "Union is underpinned by a complex and novel institutional balance," which relied "primarily on the interaction and co-operation between

108. See, e.g., GRÁINE DE BÚRCA, The Quest for Legitimacy in the European Union, 59 MOD. L. REV. 349 (1996); Craig, supra note 96 , at 112.

109. See generally Report of the Reflection Group, SN 520/95 December 1995, at vii, available at http://www.europa.eu.int.

110. Id., 179 .

111. EUROPEAN UNION-COUNCIL, REPORT OF THE COUNCIL ON THE FUNCTIONING OF THE TREATY ON EUROPEAN UNION 116 (1995) [hereinafter REPORT OF THE COUNCIL]. 
the European Parliament, the Council and the Commission." 112 For the Commission, maintenance of the "equilibrium of the institutional triangle" was an essential facet of any discussion of legitimacy in the Community. ${ }^{113}$ In this triangle, the Council represented state interests directly, and the EP interests of the people. The Commission saw its own legitimacy as guardian of the Treaty objectives, with accountability being enhanced by the new approval procedure introduced by the TEU. The preservation of institutional balance was also a feature of the EP's Report. ${ }^{114}$ While the EP believed that it had the strongest direct democratic credentials, its Report accepted the idea of institutional balance as a guiding principle for the Community as a whole.

The preservation of the Commission's right of legislative initiative was integrally related to that of institutional balance. Thus the Reflection Group stated that "the maintenance of the Commission's monopoly of initiative is a fundamental aspect of the institutional balance of the Community." "115 The Commission was, not surprisingly, of like mind on this. It has always regarded the retention of this right as its gold standard, and has resisted pressure for change from the EP. Its Report for the 1996 IGC was in the same vein. ${ }^{116}$ The Council was also opposed to any such diminution of the Commission's power, in part because it could already initiate legislation, through the use of Article $208,{ }^{117}$ and in part because the principal beneficiary of any change would be the EP, with a consequential increase in its power vis-à-vis the Council. More surprisingly, the EP did not press for its own independent right of legislative initiative on this occasion, as it had done hitherto. It did not appear on its own "shopping list" for the 1996 IGC. ${ }^{118}$ The rationale for not pressing this issue was almost certainly political. It probably felt, correctly, that its chances of

112. EUROPEAN COMMISSION, REPORT ON THE OPERATION OF THE TREATY ON EUROPEAN UNION, (SEC 95) 731, ๆ 18(1) (1995), available at $\mathrm{http}$ //europa.eu.int/en/agenda/igc-home/eu-doc/commissn/reports.html [hereinafter REPORT ON THE OPERATION OF THE TEU].

113. Id. ๆ 39.

114. Resolution of the European Parliament on the Functioning of the Treaty on European Union with a View to the 1996 Intergovemmental Conference, 1995, I 18, available at http://www.europa.eu.int [hereinafter Resolution of the European Parliament].

115. Report of the Reflection Group, supra note 107, \109.

116. REPORT ON THE OPERATION OF THE TEU, supra note 112, \$T $23,39$.

117. Previously art. 152.

118. Resolution of the European Parliament, supra note 114, $\uparrow 23$. 
success were very slim and that failure on this front might prejudice other gains which it hoped to obtain from the 1996 IGC. ${ }^{119}$

There was general consensus that reform of the legislative procedures was essential. The EP wished to have coequal legislative status with the Council, with the codecision procedure applicable for all major legislation made under the Community pillar. ${ }^{120}$ The Commission's Report acknowledged the existing problems with the range of legislative procedures. ${ }^{121}$ In a later report, ${ }^{122}$ it came out in favor of an approach akin to that of the EP, with a simplified codecision procedure being used for all main Community legislation. The assent procedure would still be used for constitutional matters, such as new entrants, international agreements, and the like. The Council's Report was, as might be expected, more equivocal. The complexity of the existing arrangements was acknowledged, ${ }^{123}$ but there was no explicit acceptance that the EP should have a coequal status in the legislative process. The Reflection Group, notwithstanding its intergovernmental orientation, came close to the position favored by the EP. ${ }^{124}$

The major reports that preceded the Amsterdam Treaty all raised institutional and substantive concerns over the operation of pillars two and three. In institutional terms, they noted that the procedures in these areas were not functioning well. In substantive terms, there was tension from the very fact that the EU had become involved in these areas at all. This, in itself, had partially fuelled the debate about legitimacy within the EU, since these new responsibilities had classically been the preserve of the nation-state.

\section{B. The Treaty of Amsterdam: Institutional and Substantive Change}

The Treaty of Amsterdam (ToA) made less sweeping changes than had the TEU. The 1996 IGC was consciously directed to consolidation, not significant steps forward. The sense of consolidation was reinforced by the realization that the major item on the 1996 agenda, the institutional implications of

119. The EP did press for amendment to what was Art. 138b, now Art. 192, to require the Commission to respond to requests made by the EP.

120. Resolution of the European Parliament, supra note 114, \29.

121. REPORT ON THE OPERATION OF THE TEU, supra note 112, I 52.

122. Scope of the Co-Decision Procedure, Commission Report under Article 189b(8), SEC(96) 1225/4, July 1996, available at http://europa.eu.int/abc/doc/off/bull/en/9607/i1001.htm.

123. REPORT OF THE COUNCIL, supra note 111, I 26.

124. See Report of the Reflection Group, supra note 109, IT $84,86$. 
enlargement, was not going to be addressed. The Treaty that emerged did nonetheless contain noteworthy institutional and substantive changes.

The principal institutional change was the blurring of the lines between the three pillars. We have already seen that the TEU drew a sharp line between decisionmaking under the Community Pillar and under CFSP and JHA. In these latter contexts, the decisionmaking remained much more intergovernmental in nature. The ToA blunted the sharpness of this divide. This was in part through the incorporation of a large section of pillar threedealing with matters such as visas, asylum, and immigration-into the Community pillar, albeit with a somewhat more restricted role than normal for the ECJ. It was also in part because the remainder of pillar three, which now covered police and judicial cooperation in criminal matters (PJCC),${ }^{125}$ allowed some greater role for the ECJ and EP than hitherto.

A further institutional change introduced by the ToA related to differential integration. There were of course instances of differential integration long before $1996,{ }^{126}$,but the ToA introduced general enabling provisions. Under Article 11, the Council could authorize "closer co-operation" between Member States if stringent conditions were met. Thus, for example, closer cooperation between certain Member States could not be undertaken if, inter alia, the area fell within the exclusive competence of the Community; if it affected Community policies, actions or programs; or if it would lead to discrimination between nationals of Member States.

There were also changes that affected the institutional balance within the Community pillar. We have already seen that the reports which led to the IGC were replete with references to the need to simplify the legislative procedures. A cursory glance at the EC Treaty after the ToA amendments would seem to indicate that little had changed in this respect. However, closer inspection of the ToA revealed that the central change recommended by the EP, the Commission, and the Reflection Group, to the effect that the codecision procedure should become the principal legislative procedure within the EC

125. The general aim of the modified Pillar Three was declared to be the creation of an area of freedom, security, and justice, by developing 'common action' in three areas: police co-operation, judicial co-operation in criminal matters, and the prevention and combating of racism and xenophobia. Particular targets mentioned are terrorism, drug and arms trafficking, trafficking in persons, offenses against children, corruption, and fraud.

126. See generally FILIP TUYTSCHAEVER, DIFFERENTIATION IN EUROPEAN UNION LAW (1999); CONSTITUTIONAL CHANGE IN THE EU: From UNIFORMITY to Flexibility? (Gráinne de Búrca \& Joanne Scott eds., 2000). 
Treaty, had largely been achieved. The codecision procedure was amended and extended to a wider range of Community policies. This further consolidated the EP's role in the decisionmaking process. The changes made to the codecision procedure strengthened the EP's position within that procedure. There were other changes designed to enhance the legitimacy of the Union, including, for example, the new provision in Article 255 on access to documents.

The ToA will be remembered, whether affectionately or not, for the fact that it renumbered all the Articles of the EC Treaty and the TEU. There were strong arguments for change. Many of the old Treaty Articles were simply redundant, and had been so for some considerable period of time. The amendments introduced by the SEA and the TEU had produced an unwieldy set of EC Treaty articles, which employed a mixture of numbers, combined with letters. This complexity was compounded by the fact that the TEU itself used a different type of numbering (Article A, B, etc). The ToA had, moreover, moved part of pillar three into pillar one. Room had therefore to be created for these new Treaty Articles. In addition there were new provisions of the EC Treaty, and these could not readily have been accommodated without a renumbering of the Treaty articles.

There were also some significant substantive changes made by the ToA. The common provisions of the TEU were amended. Article 1 TEU now provided that decisions within the EU were to be taken "as openly as possible," and as closely as possible to the citizen. Article $6 \mathrm{TEU}$ was amended to declare that the Union was founded on respect for human rights, democracy, and the rule of law. Respect for these principles was made a condition of application for membership of the European Union under Article 49 TEU. ${ }^{127}$

There were also substantive changes to the Community Treaty. Article 2 EC now included equality between men and women as an object of the Community. Environmental protection was listed as an independent goal rather than merely as a side effect of economic growth. The promotion of a high degree of competitiveness was included as a Community task, and economic development was to be "sustainable" as well as balanced and harmonious.

127. The principle contained in Art. 6 TEU was reinforced by a new Art. 7. This states that if the Council finds a "serious and persistent breach" by a Member State of principles set out in Art. 6, the Council may suspend some of that state's rights under the Treaty, including voting rights, albeit without affecting the relevant state's obligations. 
Article $13 \mathrm{EC}$ conferred legislative competence on the Community to combat discrimination based on sex, racial or ethnic origin, religion or belief, disability, age, or sexual orientation. There was a new title on employment to be found in Articles 125 through 130. Community power in relation to public health was enhanced. ${ }^{128}$ The interests of consumers now included promoting their right to information, education, and the ability to organize themselves in order to safeguard their interests. ${ }^{129}$

\section{Institutional Developments Independent of Amendment to the Treaty}

The preceding discussion has shown that formal Treaty amendment only tells part of the story about the institutional balance of power within the EU. This is as true for the period running from Amsterdam to Nice as it was for that between Rome and the SEA. Paying exclusive regard to Treaty revision would miss three important developments which had an impact, albeit in differing ways, on the institutional balance of power.

The first concerns the role of the European Council, and the way in which it interacts with other Community institutions. We have already seen the importance of the European Council in the discussions of the SEA and the TEU. The ToA had nothing significantly new to say about it, but its role has continued to evolve nonetheless. The Presidency's Conclusions have always constituted the highest-level soft law, shaping the direction and timing of policy for the Union as a whole. The range of subject matter considered at such meetings has expanded in the 1990s. This has been matched by increasing detail and variety in the high-level soft law which emerges from these summits. Most European Council meetings now have lengthy appendices, which take the form of declarations, resolutions, reports and the like, on the different topics discussed. ${ }^{130}$ It might be thought that this lends support to the liberal intergovemmentalist thesis, with its state-centric view of the integration

128. Treaty Establishing the European COMmunity, Nov. 10, 1997, O.J. (C 340) 3 (1997), art. 152, available at http://europa.eu.int/eur-lex/en/treaties/dat/ec_cons_treaty_en.pdf [hereinafter EC TREATY].

129. Id., art 153.

130. See, e.g., Lisbon European Council: Presidency Conclusions, 23-24 March 2000, available at http://www.europa.eu.int/council/off/conclu/index.htm; Santa Maria da Feira European Council: Presidency Conclusions, 19-20 June 2000, available at http://www.europa.eu.int/council/off/conclu/index.htm; Nice European Council, 7-9 December 2000, available at http://www.europa.eu.int/council/off/conclu/index.htm; Stockholm European Council: Presidency Conclusions, 23-24 March 2001, available at http://www.europa.eu.int/council/off/conclu/index.htm. 
process. This would be overly simplistic; it is readily apparent that the evolution of policy will not be the preserve of the European Council alone. To the contrary, other institutional actors, such as the Commission, and the EP, will play a role which cannot be relegated to that of mere delegate or agent. Thus the development in policy concerning the internal market has been the result of a symbiotic relationship between the Commission, the Internal Market Council, and the European Council. ${ }^{131}$ Ideas initially elaborated in one institutional setting will be amplified in another, and then returned for further refinement. Nor is this necessarily a conscious, pre-ordained process. The fact that one can with hindsight discern the emergence of a new or modified policy should not lead one to think that this was neatly planned in advance. The institutional interaction between the European Council, Commission and other players related as much to the gradual emergence of the policy itself as to its execution.

The second important development was the proliferation of institutional forms through the use of agencies. We have already seen that the need to delegate power was recognized in the original Rome Treaty. We have seen also that the unwillingness of the Council to hand over a blank check to the Commission was the principal rationale for the creation of the committee structure now known as Comitology. More recently the institutional structure has been developed through the use of agencies. There were two agencies established in 1975, and eight more since $1994 .{ }^{132}$ In EC terminology, they are referred to as "satellite bodies." They possess legal personality; have management boards on which Member State influence predominates, although there is some supranational representation; they operate outside the Commission and Council; and they were, with one exception, each established pursuant to a regulation made under Article $308 .{ }^{133}$ Seven of the agencies are concerned with the collation and dissemination of information, two have de

131. See generally Paul Craig, The Evolution of the Single Market, in THE LAW OF THE SINGLE EUROPEAN MARKET: UNPACKING THE PREMISES (Catherine Barnard and Joanne Scott eds., 2002).

132. European Centre for the Development of Vocational Training, European Foundation for the Improvement of Living and Working Conditions, European Environment Agency, European Training Foundation, European Monitoring Centre For Drugs and Drug Addiction, European Agency for the Evaluation of Medicinal Products, Office for Harmonization in the Internal Market, European Agency for Safety and Health at Work, Community Plant Variety Office and European Translation Centre for Bodies of the EU. The first two agencies mentioned were established in 1975.

133. Alexander: Kreher, Agencies in the European Community-A Step Towards Administrative Integration in Europe, 4 J. EUR. PUB. POL'Y. 227 (1997). 
facto executive/regulatory powers in relation to Community trademarks and plant variety rights, and one has quasi-executive capacity in relation to medicines. ${ }^{134}$ In formal terms, the degree of agency autonomy is constrained by ECJ jurisprudence which limits the delegation of power to bodies are not mentioned in the constituent Treaties. ${ }^{135}$ In substantive terms, the degree of autonomy possessed by each agency varies considerably, depending upon the composition of its governing board, its financing and the subject matter with which it deals. ${ }^{136}$

There are differing views as to the rationale for the use of the agency structure. Kreher contends that agency creation fosters administrative integration. ${ }^{137}$ Dehousse ${ }^{138}$ argues that agency creation is a response to conflicting pressures at work within the Community. There is a sense that legislative harmonization is insufficient to dismantle barriers to trade, and that some greater convergence of administrative practice is required. There is also the growing recognition that further delegation of direct administrative responsibility to the Commission may be problematic. Regulation by networks, whereby national and Community administrators come together to try and achieve a uniform response, is said to be the way out of this conundrum. The Comitology process is itself the prime example of this form of networking. Many of these committees have developed from bodies whose prime function is to oversee the Commission in the discharge of power delegated to it by the Council, into forums through which national administrators can meet to attempt to find a uniform strategy for implementation. The ad hoc nature of these committee meetings is, however, a drawback, and Dehousse therefore sees agencies as a more permanent institutionalized locus through which such networking designed to reach the requisite uniformity can take place. ${ }^{139}$ Shapiro's view is less prosaic. ${ }^{140}$ If direct routes to further political integration

134. The bodies with some de facto executive power are the Office for Harmonization and the Community Plant Variety Office. The EMEA has some quasi-executive capacity.

135. Koen Lenaerts, Regulating the Regulatory Process: "Delegation of Powers" in the European Community, 18 EUR. L. REV. 23 (1993); Michelle Everson, Independent Agencies: Hierarchy Beaters?, 1 EUR. L. J. 180 (1995).

136. See Kreher, supra note 133, at 238.

137. Id. at $239-40$.

138. Renaud- Dehousse, Regulation by Networks in the European Community: The Role of European Agencies, 4 J. EUR. PUB. POL'Y. 246 (1997).

139. Id. at 254-55.

140. Martin-Shapiro, The Problems of Independent Agencies in the United States and the European Union, 4 J. EUR. PUB. POL'Y. 276, 281 (1997). 
are presently unacceptable, then it is best to proceed via the creation of small discrete technical units which have the added advantage of not being the Commission, and not being in Brussels. The creation of relatively small agencies, each with a particular remit, is, Shapiro feels, also more likely to lead to the creation of "Europe-wide epistemic communities" of technocrats "whose technical truths transcend intergovernmental politics.",141

The third significant institutional development was the crisis leading to the resignation of the Commission. ${ }^{142}$ A real appreciation of the events which led to the resignation of the Santer Commission requires a grasp of the way in which the Commission functions. It necessitates in particular an understanding of the distinction between direct and shared administration, and the respective difficulties with each of these modes of delivering policy. Suffice it to say for the present that there had been concern about fraud and mismanagement. This came to light from newspaper reports and investigations by the Court of Auditors. The European Parliament repeatedly expressed its dissatisfaction with the management of the Community's financial resources. This culminated in a resolution on January 14, 1999 which called for a Committee of Independent Experts to be convened under the auspices of the EP and the Commission, with a mandate to detect and deal with fraud, mismanagement, and nepotism. The Committee was also to conduct a fundamental review of the Commission's practices in the award of all financial contracts. The Committee produced its first report within two months, by March 15, 1999. ${ }^{143}$ This had an immediate and dramatic effect: the Commission resigned en bloc. The resulting crisis was the dominant headline in newspapers across Europe. The Second Report of the Committee of Independent Experts ${ }^{144}$ received far less attention and passed almost unnoticed by the press. The two reports set in train discussion which led to the White Paper on Reform of the Commission. ${ }^{145}$ It is

141. Id. at 282 .

142. Paul Craig, The Fall and Renewal of the Commission: Accountability, Contract and Administrative Organization, 6 EUR. L. J. 98 (2000).

143. COMMITTEE OF INDEPENDENT EXPERTS, FIRST REPORT ON ALLEGATIONS REGARDING FRAUD, MiSMANAGEMENT AND NEPOTISM IN THE EUROPEAN COMMISSION I 1.4 .2 (Mar. 15, 1999), available at http://www.europarl.eu.int/experts/pdf/reporten.pdf.

144. COMMITTEE OF INDEPENDENT EXPERTS, SECOND REPORT ON REFORM OF THE COMMISSION, ANALYSIS OF CURRENT PRACTICE AND PROPOSALS FOR TACKLING MISMANAGEMENT, IRREGULARITIES AND FrAUD (Sept. 10 1999), available at http://www.europarl.eu.int/experts/default_en.htm.

145. Reforming the Commission: White Paper from the Commission of the European Communities, $\operatorname{COM}(2000) 200$ final, available at http://europa.eu.int/eur-lex/en/com/wpr/2000/act200en0l/ com2000_0200en01-01.pdf. 
important to recognize that the IGC discourse that led to the Nice Treaty about institutional reform pending enlargement was conducted against the background of discussion about internal Commission reform.

\section{THE NiCE TREATY: INSTITUTIONAL BALANCE AND ENLARGEMENT}

The IGC which led to the Nice Treaty was almost entirely preoccupied with the issue which had been ducked in Amsterdam: the institutional consequences of enlargement. It therefore provided an especially interesting focus for the dynamics of institutional balance within the Community. Previous Treaty negotiations focused on the relative and respective powers of Council, Commission, and EP. In contrast the main focus of the discussions leading to the Nice Treaty was on intra rather than interinstitutional balance. The debates saw divisions drawn between large, medium, and small states about the institutional consequences of enlargement within the Commission, Council, and the EP. It is true that differences between states as to the disposition of power within the main Community institutions had affected earlier Treaty revisions, but in the IGC leading to the Nice Treaty, this was the primary focal point of the negotiations.

For seasoned IGC watchers, these negotiations provided a powerful reminder that the devil is in the details. Abstract generalizations about the powers of the respective institutions do not take one far. Treaty renegotiation is necessarily and inevitably about the fine-tuning of the institutions' powers. The Member States and other major players fought long and hard over issues which might seem to the outsider matters of arcane detail. This is precisely because the detail is itself reflective of broader issues of principle. It is the detail that encapsulates the principles shaping the reality of intra and interinstitutional power in the Community. The disposition of this power cannot readily be understood without some idea of the key debating points relevant to each institution. It is only then that one is in a position to make any assessment as to the institutional balance of the Community as a whole.

Institutional reform of the Council occupied more of the IGC's time than any other topic. The negotiation centered on the extension of qualified majority voting and the weighting of votes. All acknowledged that there had to be an extension of qualified majority voting in an expanded Union. Unanimity would often be synonymous with inaction, since one state out of twenty-seven would almost certainly object. Forging agreement on the areas where there should be a shift to qualified majority proved more difficult. Discussions in the IGC were 
akin to a series of individual skirmishes as to whether another bastion of unanimity should be given up. A fact rarely acknowledged was that the veto was always a double-edged sword: it could protect state autonomy, but it could equally prevent Union action. Much then depended on whether states felt that they would more often be "vetoed against" than "exercisers of veto power" themselves.

The options canvassed as to weighting of votes approached the byzantine in terms of complexity. The reasons are not hard to find. The issue cast into sharp relief the relative power of large, medium, and small states in the Council. Discussion focused on a dual majority system, the central element of which was the fixing of a threshold in terms of majority of the population coupled with majority of the states, or a simple reweighting model, albeit one which took some account of population and the number of Member States. ${ }^{146}$ The later stages of the IGC concentrated on three variants of the latter model: weak, moderated, and substantial moderating. Weak reweighting coupled with a population safety net to ensure that any qualified majority would comprise at least fifty-eight percent of the Union's population. Moderated reweighting meant that a qualified majority would comprise a percentage of the Union's population close to the present percentage. Substantial reweighting was premised on the assumption that a qualified majority would cover over sixty percent of the population. The Member States with larger populations favored substantial reweighting. They were concerned that the accession of new, small states would otherwise weaken the relative weight of the larger states, and the population they represent, in the Council. Member States with smaller populations supported weak or moderate reweighting and argued that this sufficiently protected the position of the larger states.

The solution embodied in the Nice Treaty was in reality midway between moderate and substantial reweighting. It is found in the Protocol on Enlargement of the Union, coupled with Declaration 20 on Enlargement, and is posited on a Union with twenty-seven states. The Protocol comes into effect on January 1,2005 . The votes accorded to each of the states have been "stretched" to accommodate the new, smaller states. The largest states have twenty-nine votes each, the smallest three, with gradations in between. The

146. Conference of the Representatives of the Governments of the Member States, Presidency Note: IGC 2000-Weighting of Votes, CONFER 4754/00 (May 24, 2000); Working Document, IGC 2000: Weighting of Votes in the Council, CONFER 4796/00, (Nov. 9 2000). 
votes accorded to the largest states are greater than those proposed for moderate reweighting, but less than in the substantial reweigthing model. Prior to enlargement a qualified majority will be 169 out of 237 in cases where the Council acts on a proposal from the Commission. Where it does not do so, there is the additional requirement that the votes must be cast by at least twothirds of the states. After enlargement a qualified majority will be 258 out of 345. The other rules are the same. The wishes of the larger states have been further reinforced by the addition of Article 205(4), which allows a member of the Council to request verification that the states constituting the qualified majority represent at least sixty-two percent of the population. If this condition is not met, the relevant decision cannot be adopted.

The discussion of the EP focused principally on its size and the distribution of seats in an enlarged Community. The IGC rapidly came to the conclusion that a meaningful upper limit on the number of seats had to be maintained. ${ }^{147}$ To do otherwise would be to expand beyond the limit of 700 set in the ToA ${ }^{148}$ to a total of 963 in an enlarged Community. The focus then shifted to the method for deciding on the allocation of seats. One option was for there to be an across-the-board linear reduction in the number of seats for each Member State. The existing criterion for allocation would be retained, and there would be a maximum of 700 MEPs for the Community as a whole. This was opposed by the larger states, which would, in relative terms, be underrepresented. The other option, favored by the EP itself, ${ }^{149}$ was for seat allocation to be proportionate to population, subject to the caveat that there would be a minimum number of MEPs from each Member State. Neither of these options was likely to achieve consensus in its own right, ${ }^{150}$ and a compromise was built into the Nice Treaty, based on greater proportionality in seat allocation than

147. Conference of the Representatives of the Governments of the Member States, Presidency Note: IGC 2000-Other Amendments to Be Made to the Treaties with Regard to the European Institutions, CONFER 4740/00, (May 10 2000), available at http://db.consilium.eu.int/cigdocs/EN/04740en.pdf.

148. EC TREATY art. 189.

149. Report on the European Parliament's Proposals for the Intergovernmental Conference, Part 1: Motion for a resolution, EUR. PARL. DOC. (A5-0086/2000 final edition) (Mar. 27, 2000).

150. Conference of the Representatives of the Governments of the Member States, Presidency Note: IGC 2000-Le Parlement Européen, CONFER 4771/00, available at http://europa.eu.int/comm/archives/igc2000/ geninfo/confer4771_fr.pdf; Conference of the Representatives of the Govemments of the Member States, Presidency Report to the Feira European Council, CONFER 4750/00, 33-6 (2000), available at http://db.consilium.eu.int/cigdocs/EN/04750en.pdf; Conference of the Representatives of the Govemments of the Member States, Presidency Note: IGC 2000-Allocation of Seats in the European Parliament, CONFER $4805 / 00$ (2000), available at $\mathrm{http}: / / \mathrm{db}$.consilium.eu.int/cigdocs/EN/4805en.pdf. 
hitherto, though still less than advocated by the EP. Article 189 was modified to set the upper limit of MEPs at 732. The allocation of seats was set out in a Protocol attached to the Nice Treaty, and comes into effect on January 1, $2004 .{ }^{151}$ Declaration 20, attached to the Nice Treaty, lays down the allocation of seats in an EU with twenty-seven Member States.

The institutional implications of enlargement for the Commission raised a number of important issues. Much consideration was given to the size of the Commission. Opinion in the IGC was divided as to whether there should continue to be one Commissioner from each state, or whether there should be an upper limit combined with a system of rotation. ${ }^{152}$ The argument for the latter view was in part conceptual, in the sense that Commissioners do not in any event represent their state. It was also in part practical, in that the operation of a Commission with twenty-seven or twenty-eight Commissioners was felt to cross the line between a collegiate body and a deliberative assembly. The Nice Treaty embodied a compromise in this respect. The Protocol on Enlargement provided that from January 1, 2005, Article 213(1) should be amended to provide that the Commission consist of one national from each state. When the Union has twenty-seven Member States, Article 213(1) will be further modified such that the number of Commissioners will be less than the number of Member States. The Council, based on the principle of equality, will adopt a rotation system. It will also be for the Council to decide on the number of Commissioners.

The Nice Treaty makes other important changes in relation to the Commission. Article 214(2) is amended such that the nomination of the President of the Commission will be by qualified majority, rather than common accord. The logic of this change is carried over to Article 215, dealing with replacement of a Commissioner. The powers of the Commission President have been reinforced through changes to Article 217. The Commission works under the political guidance of the President, who will decide on its internal organization in order to ensure that it acts consistently, efficiently, and on the basis of collegiality. The President was given formal powers to allocate

151. Treaty of Nice Amending the Treaty on European Union, the Treaties Establishing the European Communities and Certain Related Acts, Oct. 3, 2001, O.J. (C 80) I (2001), art. 2, available at http:// europa.eu.int/eur-lex/en/treaties/dat/nice_treaty_en.pdf.

152. Conference of the Representatives of the Governments of the Member States, Presidency Note: IGC 2000-Size and Composition of the Commission, CONFER 4813/00, (Dec. 1, 2000), available at http:// db.consilium.eu.int/cigdocs/EN/4813en.pdf. 
portfolios, and to reshuffle them. The President was also empowered to request the resignation of a Commissioner, after obtaining the approval of the College. A provision such as this might have forestalled some of the crisis which led to the downfall of the Santer Commission.

The discussion of the post-Nice institutional balance so far as it relates to the Commission would be defective if it did not take into account the reforms which took place outside the IGC. The crisis following the fall of the Santer Commission led, as we have seen, to a widespread reevaluation of its internal structure and operation. ${ }^{153}$ The detailed reforms to be implemented after the White Paper ${ }^{154}$ will affect not only the internal order of the Commission itself, but will also have ramifications for the way in which it interacts with the other major Community institutions.

The Nice Treaty made other changes which could have an impact on the overall nature of decisionmaking. The provisions on flexibility were altered so as to render it easier for them to be used in an expanded Union. Whether they are used remains to be seen.

It is common for IGCs to leave much on the "cutting room floor." Proposals are put forward, and may well be taken to an advanced stage, only to be dropped because of failure to secure the requisite support needed for inclusion in the final Treaty amendment. The most significant such casualty that would have affected the Community's institutional balance was concerned with the legislative process itself. There were suggestions to include some element of a hierarchy of norms within the Treaty. ${ }^{155}$ The main aspect of this was to be amendment to Article 251, the codecision procedure. The idea was that measures enacted under this procedure would define the general principles, the objectives to be attained, and the essential elements of the measures to be taken. Matters of detailed implementation would then be enacted under other processes, requiring less input from the European Parliament. Suggestions along these lines survived into the autumn of $2000,{ }^{156}$ but did not find their way into the Nice Treaty itself.

153. Craig, supra note 142.

154. Reforming the Commission, supra note 145.

155. E.g., Presidency Note, supra note 146; Legal Adviser, SN 3068/00, May 302000.

156. Conference of the Representatives of the Governments of the Member States, Progress Report on the Intergovemmental Conference on Institutional Reform, CONFER 4790/00, Nov. 3, 2000, available at http://db.consilium.eu.int/cigdocs/EN/4790en.pdf. 
It is also common for IGCs to leave for future deliberation matters on which consensus could not be reached within the available time. This was the case in relation to the Charter of Fundamental Rights of the European Union. ${ }^{157}$ The Charter was drafted by a body, called the Convention, which operated independently of the IGC. The Charter was approved by the European Council at Nice, but the crucial question as to its precise legal status was put aside until 2004.

\section{INSTITUTIONAL BALANCE: LAEKEN AND BEYOND}

The Laeken European Council ${ }^{158}$ laid the institutional foundations for the next round of Treaty reform. It established a Convention, headed by Giscard d'Estaing, with two Vice Chairmen, a representative from each state, two national members of Parliament from each country, sixteen MEPs, and two Commission representatives. The accession candidate countries were fully involved in the Convention proceedings. The Convention began its deliberations in March 2002, with the object of completing them within one year. The Convention will consider the division of competence between the EU and Member States, simplification of the Union Treaties, the status to be given to the Charter of Rights, the possibility of a European Constitution, and moves to enhance democracy, efficiency and transparency in the EU. Each of these areas was given a broad reading in the Laeken Declaration. We shall therefore have to await the outcome of the Convention to determine the conclusions reached on these topics, being mindful that the final Convention document will be the starting point for discussion in the IGC, which will make the ultimate decisions.

157. 2000 O.J. (C 364) 1 (2000), available at http://europa.eu.int/eur-lex/pri/en/oj/dat/2000/c_364/ c_36420001218en00010022.pdf.

158. Dec. 14-15 2001. 